\title{
Levels of Heavy Metals in Soil, Water and Vegetables around Industrial area in Bauchi, Northeastern Nigeria
}

\section{1'SULAIMAN, BA; *2SULAIMAN, MB; ${ }^{3}$ AHMED, A; ${ }^{4}$ MAIGARI, IA; ${ }^{5}$ TIJJANI, AF}

\author{
${ }^{I}$ Department of Pure and Applied Chemistry, University of Maiduguri, Borno State, Nigeria \\ ${ }^{* 2}$ Department of Pure and Industrial Chemistry, University of Nigeria, Nsukka, Enugu State, Nigeria \\ ${ }^{3}$ Department of Science Laboratory Technology, Federal Polytechnic Mubi, Adamawa State, Nigeria \\ ${ }^{4}$ Department of Science Laboratory Technology, Gombe State Polytechnic, Bajoga, Gombe State, Nigeria \\ ${ }^{5}$ Department of Science Laboratory Technology, Federal Polytechnic of Oil and Gas, Bonny Island, River's State, Nigeria \\ *Corresponding Author Email:sulaimanmuhammadbashir@gmail.com;mohammad.sulaiman.pg01935@unn.edu.ng
}

\begin{abstract}
This study examined the levels of heavy metals in soil, water, and vegetables (amaranthus, hibiscussabdariffa, and allium cepa leaves) around the industrial area Bauchi, Northeastern Nigeria. The composite samples of soil, water, and vegetables were collected and determine the level of heavy metals $(\mathrm{Mn}, \mathrm{Zn}, \mathrm{Cd}, \mathrm{Pb}$, and $\mathrm{As}$ ) using Atomic Absorption Spectrophotometer (AAS). The level of the heavy metals decreased in the order of $\mathrm{Mn}>\mathrm{Zn}>$ $\mathrm{Pb}>\mathrm{Cd}, \mathrm{Pb}>\mathrm{Zn}>\mathrm{Mn}>\mathrm{Cd}$, and $\mathrm{Mn}>\mathrm{Zn}>\mathrm{Mn}>\mathrm{Cd}$ in the soil, water, and vegetables respectively. Among the vegetables, amaranthus had the highest heavy metals level followed by allium cepa leaves and hibiscus sabdariffa. The levels of heavy metals obtained were below the tolerance level recommended by the world health organization (WHO). The bio-concentration factors of the heavy metals for the studied samples were below one except $\mathrm{Zn}$ in amaranthus. The daily intake of metals for $\mathrm{Mn}$ was found to be the highest in amaranthus for children and estimated to be 1.149 $\mathrm{mg} / \mathrm{person} /$ day. Health risk index of $\mathrm{Zn}$ for amaranthus and allium cepa leaves for children and $\mathrm{Pb}$ for amaranthus, hibiscus sabdariffa and allium cepa leaves for both children and adults were above 1, except in hibiscus sabdariffa for adults, signifying provable of health risks for the consumption of the vegetables in the study area. Therefore, the consumption of these vegetables as food could pose a health hazard, and regular monitoring is recommended to prevent metal accumulation with their associated health implications in the consuming public.
\end{abstract}

\section{DOI:https://dx.doi.org/10.4314/jasem.v25i8.37}

Copyright: Copyright $\left({ }^{\circ} 2021\right.$ Sulaiman et al. This is an open access article distributed under the Creative Commons Attribution License (CCL), which permits unrestricted use, distribution, and reproduction in any medium, provided the original work is properly cited.

Dates: Received: 10 May 2021; Revised: 28 June 2021; Accepted: 01 July 2021

Keywords; Heavy Metals, vegetable, daily intake of metals, health risk index

Environmental pollution has been one of the most serious global challenges facing communities living in an industrial area, particularly in developing countries like Nigeria. Environmental pollution can as a result of unfavorable production of man's activities such as mining, combustion, applications of fertilizers and pesticides (Reynolds et al., 2015; Hazrat et al., 2019). Chemical substances from the activities such as heavy metals are one of the factors which contribute to environmental pollutions and it was believed that it can disrupt the living ecosystem (Kabata-Pendias and Pendias, 2001). Currently, anthropogenic inputs of metals above the natural levels due to an increase in industrialization and urbanization (Varalakshmi and Ganeshamurthy, 2010, Sulaiman et al., 2020). Industrial wastes, atmospheric deposition from crowded cities, and other domestic wastes are among the major sources of heavy metals in the surface water, groundwater, and soils (Raymond et al., 2011; Qingwei et al., 2020). Heavy Metals are natural constituents of the earth's crust, with an atomic density greater than $5 \mathrm{gcm}^{-3}$, an atomic number $>20$ and the most common heavy metal contaminants are $\mathrm{Cd}, \mathrm{Cr}$, $\mathrm{Cu}, \mathrm{Hg}, \mathrm{Pb}$, and $\mathrm{Zn}$ (Garba et al., 2018). Heavy metals have been given considerable concern worldwide due to their toxicity and accumulative behavior (Alinnor, 2008; Sulaiman et al., 2019a). Heavy metal contamination of soil, water, and atmosphere signifies a rising environmental problem that may enter the food chain as a result of their uptake by edible plants, affecting food quality and human health (Chibuike and Obiora, 2014; Zwolak et al., 2019; Hazrat et al., 2019). Heavy metals in a surface, groundwater and soils could either from natural or anthropogenic sources (Duke and Williams, 2008; Vhahangwele and Khathutshelo, 2018). The consumption of vegetables and fruits as food offer rapid and least means of providing adequate vitamin supplies, minerals, and fiber. Vegetables are used as food include those used in making soups or served as integral parts of the main sources of a meal (Arora, 2008), but the accumulation of heavy metals in the soil may affect soil properties and inhibit plant growth. Moreover, several studies showed that fruits and leafy vegetables are vulnerable 
to heavy metals contamination from air, water, and soil (Sulaiman et al., 2019b). The consumption of vegetable growth in contaminated soils is one of the contributing factors to human exposure to heavy metals (Zhuang et al., 2009; Ogbonna and Okezie, 2011; Sulaiman et al., 2019b). On the other hand; $\mathrm{Pb}$ is relatively highly toxic to higher animals. It is absorbed and translocated to plant tissues, from which it affects animals and humans when consumed with plants (Rodríguez et al., 2018). Thus, the evaluation of the levels of heavy metals in environmental samples is very important. The present work, evaluate levels of heavy metals in soils, water, and some of the vegetables and assessed the health associated with consumption of the vegetables from Bauchi industrial area, Northeastern Nigeria.

\section{MATERIALS AND METHODS}

Study area: The study was conducted at Gwallaga along Bauchi industrial area, Bauchi State, northeastern part of Nigeria (Fig1). It is located between longitude $10.10^{\circ} \mathrm{N}-10.33^{\circ} \mathrm{N}$ and latitude $9.40^{\circ} \mathrm{E}-10.13^{\circ} \mathrm{E}$. It occupies an estimated land area of $3,687 \mathrm{~km}^{2}$ and altitude is $690.2 \mathrm{~m}$ above sea level. The climate is tropical with two distinct seasons; rainy (May-October) and dry/harmattan (November-April) seasons; with a temperature of between $23{ }^{\circ} \mathrm{C}$ and 40 ${ }^{\circ} \mathrm{C}$ and an average rainfall of $1.0914 \mathrm{~mm}^{3}$. The daily humidity increases to $94 \%$ in the middle of the rainy season but falls to less than $10 \%$ during the dry season (Sulaiman et al., 2018; Barambu et al., 2020).

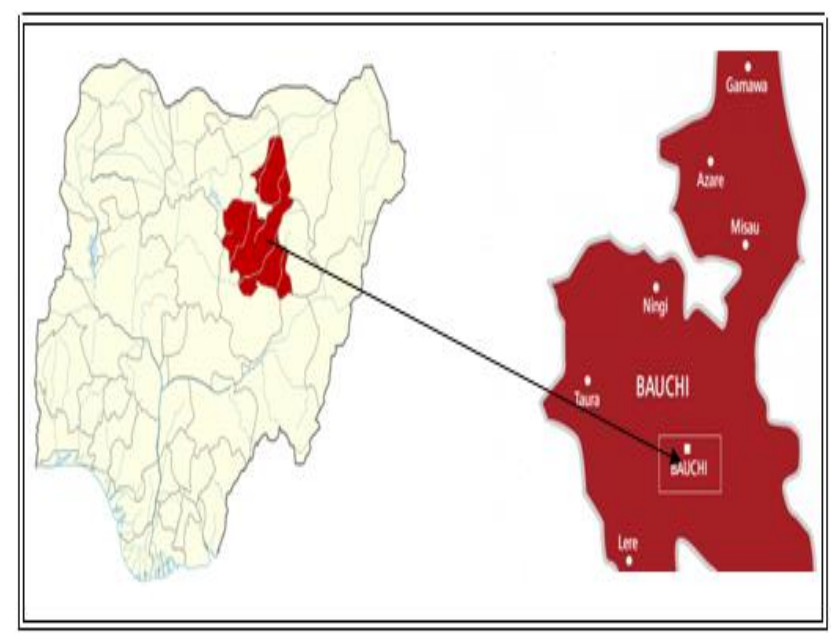

Fig 1: A map shows the study area in Bauchi, Bauchi State, Nigeria.

Samples collection: Samples of soil, water, and vegetables (amaranthus, hibiscus sabdariffa, and allium cepa leaves) were collected from Gwallaga along Bauchi industrial area, Bauchi state. All samples were randomly collected; at the sampling point, three sub-samples were collected to form a composite sample. Soil samples were collected using plastic spade up $15 \mathrm{~cm}$ depth and vegetable samples were collected from the study site. The collected soil and vegetable samples were put into clean polythene bags and labeled, while water samples were put in previously washed, rinsed, and dried bottles. A total of 12,12 , and 36 of soil, water, and vegetable samples were collected respectively. The samples were brought to the laboratory for analysis.

Soil samples preparation and analysis: The soil samples were air-dried and crushed in a mortar and pestle and passed through a $2 \mathrm{~mm}$ mesh sieve to remove debris. $2.0 \mathrm{~g}$ of air-dried sample was weighed in a beaker and few drops of distilled water were used.
$15 \mathrm{~cm}^{3}$ of aqua regia $\left(3: 1 \mathrm{HCl}: \mathrm{HNO}_{3}\right)$ was added and the mixture was heated for 1 hour at $120{ }^{\circ} \mathrm{C}, 2.0 \mathrm{~cm}^{3}$ $\mathrm{HClO}_{4}$ was added and evaporated to approximately $0.5 \mathrm{~cm}$ after cooling the residue was dissolved with $2 \% \mathrm{HNO}_{3}$, filtered before transferred to a $50 \mathrm{~cm}^{3}$ volumetric flask and made up to the mark with $2 \%$ $\mathrm{HNO}_{3}$ (Kudirat and Fummilayo, 2011).

Vegetable samples preparation and analysis: The vegetables were air-dried and grounded with mortar and pestle sieved through $2 \mathrm{~mm}$ mesh sieve, $2.0 \mathrm{~g}$ portion of the sample was weighed into $100 \mathrm{~cm}^{3}$ Kyeildal digestion flask, $15 \mathrm{ml}$ of concentrated $\mathrm{HNO}_{3}$ was added followed by $3 \mathrm{ml}$ each of concentrated $\mathrm{H}_{2} \mathrm{SO}_{4}$ and $12 \mathrm{ml} 60-62 \% \mathrm{HClO}_{4}$, in the ratio of 5:1:4 ratio respectively. The flask was cooled and the content was made up to the mark with deionized water and transferred to $125 \mathrm{~cm}^{3}$ polyethene cans and stored for heavy metal determination with (unicam 919 AAS). 
Water samples preparation and analysis: $50 \mathrm{~cm}^{3}$ of water sample was measured into a beaker. A mixture of $10 \mathrm{~cm}^{3}$ of concentrated $\mathrm{HNO}_{3}$ and $\mathrm{HCl}$ in the ratio of 1:3 was added, it was evaporated to a smaller volume and the filtrate was transferred into a $100 \mathrm{~cm}^{3}$ volumetric flask and made up to a mark with distilled water and ready for atomic absorption spectrophotometer (Unicam 919 AAS).

Bioaccumulation factor: The bioaccumulation factor is the ratio of the concentration of heavy metals in a plant to the concentration of heavy metals in soil, i.e the translocation of heavy metals from soil to vegetables (Naser et al., 2012; Sharma et al., 2018; Sulaiman et al., 2019; Gebeyehu and Bayissa 2020; Gemeda et al., 2020).

$$
\mathrm{BCF}=\frac{\mathrm{C}_{\text {plant }}}{\mathrm{C}_{\text {soil }}}
$$

Where: $\mathrm{BCF}=$ bioaccumulation, $\mathrm{C}_{\text {plant }}=$ concentration of heavy metals in plants, and $\mathrm{C}_{\text {soil }}=$ concentration of heavy metals in soil.

Daily Intake of Metal: The daily intake of metals (DIM) is the average estimated the daily metal loading into the body system of specified body weight of a consumer which notify the relative phyto-availability of metal (Mahmood and Malik, 2014; Adedokun et al., 2016; Ftsum and Abraha, 2018; Sulaiman et al., 2019).The daily intake metals (DIM) was determined using the following equation:

$$
\mathrm{DIM}=\frac{\mathrm{Cm} \times \mathrm{Cf} \times \mathrm{Dft}}{\mathrm{Bw}}
$$

Where: $\mathrm{DIM}=$ daily intake of metals, $\mathrm{Cm}=$ concentrations of metal in plants $(\mathrm{mg} / \mathrm{kg}), \mathrm{Cf}=$ conversion factor (0.085), Dft= food intake (daily intake of vegetables), $\mathrm{Bw}=$ average body weight $(\mathrm{kg})$.
Health Risk Index: The health risk assessment is a multi-step process that consists of data collection, and analyzing the site data appropriate to human health (Grzetic and Ghariani, 2008; Sulaiman et al., 2016; Sulaiman et al., 2019). The health risk index (HRI) was determined using the following equation:

$$
\mathrm{HRI}=\frac{\mathrm{DIM}}{\mathrm{R}_{\mathrm{fd}}}
$$

Where: $\mathrm{HRI}=$ health risk index, $\mathrm{DIM}=$ daily intake of metals, and $\mathrm{Rfd}=$ reference oral dose. $\mathrm{Rfd}$ values employed in this study were obtained from (US-EPA IRIS, 2006).

If the value of HRI is less than 1 then the exposed population is said to be safe (US-EPA IRIS, 2003).

\section{RESULTS AND DISCUSSIONS}

Levels of heavy metals in soil and water samples: Table 1 presents the levels of heavy metals in soil and water. The levels of heavy metals in soil were 9.47 $\mathrm{mg} / \mathrm{kg}, 1.83 \mathrm{mg} / \mathrm{kg}$, and $0.45 \mathrm{mg} / \mathrm{kg}$ for $\mathrm{Mn}, \mathrm{Zn}$, and $\mathrm{Pb}$ respectively. The highest level was found for $\mathrm{Mn}$ followed by $\mathrm{Zn}$ and $\mathrm{Pb}$, while the $\mathrm{Cd}$ and $\mathrm{As}$ were below the detectable limit. The observed levels in soil samples were below the permissible limits in agricultural soils (Table 1) FAO/WHO. The findings of the studied samples suggest that the soil samples were not polluted by the referred heavy metals. Thus, the results concluded that the soil sample of the study area was not polluted by the investigated heavy metals. The level of heavy metals in the water is in the following trend; $\mathrm{Mn}>\mathrm{Pb}>\mathrm{Zn}>\mathrm{Cd}>\mathrm{As}$, the values obtained were $0.5 \mathrm{mg} / \mathrm{L}, 0.11 \mathrm{mg} / \mathrm{L}, 0.08 \mathrm{mg} / \mathrm{L}, 0.00$ and $0.00 \mathrm{mg} / \mathrm{L}$ for $\mathrm{Mn}, \mathrm{Pb}, \mathrm{Zn}, \mathrm{Cd}$, and As respectively. The obtained levels of metals in this were below the permissible limit of water set by WHO, this indicated that activities of the study area have not affected the water quality, but regular monitoring is recommended to prevent metal accumulation.

Table 1: Heavy metals levels soil and water from Gwallaga, Industrial area, Bauchi State

\begin{tabular}{llllll}
\hline Samples & $\mathrm{Mn}$ & $\mathrm{Zn}$ & $\mathrm{Cd}$ & $\mathrm{Pb}$ & $\mathrm{As}$ \\
\hline Soil $(\mathrm{mg} / \mathrm{kg})$ & $9.47 \pm 0.021$ & $1.83 \pm 0.013$ & $0.00 \pm 0.00$ & $0.45 \pm 0.022$ & $\mathrm{BDL}$ \\
FAO/WHO & 100 & 300 & 3.00 & 50.00 & 20.00 \\
Water $(\mathrm{mg} / \mathrm{L})$ & $0.05 \pm 0.013$ & $0.08 \pm 0.010$ & $0.00 \pm 0.00$ & $0.11 \pm 0.021$ & $\mathrm{BDL}$ \\
WHO & 0.5 & 0.2 & - & 0.01 & - \\
\hline \multicolumn{5}{c}{ BDL=below detectable limit } \\
\end{tabular}

Levels of heavy metals in vegetable samples: The results of vegetable samples are presented in Table 3 . The results showed that the level of $\mathrm{Mn}$ ranged from 3.12 - $1.50 \mathrm{mg} / \mathrm{kg}$, Zn $0.60-2.08 \mathrm{mg} / \mathrm{kg}$, and $\mathrm{Pb} 0.04$ - $0.07 \mathrm{mg} / \mathrm{kg}$, while $\mathrm{Cd}$ and As were below the detectable limit. Among the vegetables, amaranthus had the highest heavy metals level followed by allium cepa leaves and hibiscus sabdariffa. The higher concentration of $\mathrm{Mn}$ was obtained in amaranthus followed by habiscussa bdariffa andallium cepa leaves, while that of $\mathrm{Zn}$ highest concentration amaranthus followed by allium cepa leaves and habiscussa bdariffa and that of $\mathrm{Pb}$ was allium cepa leaves, amaranthus, and aabiscussa bdariffa. 
Generally, the level of heavy metal in the vegetables was decreasing in the order of $\mathrm{Mn}>\mathrm{Zn}>\mathrm{Pb}$. The levels of $\mathrm{Mn}, \mathrm{Zn}$, and $\mathrm{Pb}$ in vegetables were below the permissible limits in vegetable by $\mathrm{FAO} / \mathrm{WHO}$ in (Table 2).

Bio-concentration factor: The results of the bioconcentration factor (BCF) of the heavy metals are presented in Table 3. Soil to plant bio-concentration factor coefficient is an essential factor of human exposure to heavy metals through the food chain as it describes the transfer of contaminants from soil to plants (Gupta et al., 2013; Tasrina et al., 2015; David and Minati, 2018). The results showed that the highest bio-concentration factor (BCF) value was obtained for $\mathrm{Zn}$ in amaranthus and the lowest value was obtained for $\mathrm{Pb}$ in habiscussa bdariffa. The bio-concentration factor of the heavy metals for the studied samples was below one except $\mathrm{Zn}$ in amaranthus, suggesting the possibility of health risk for consumption of vegetables grown in the study area.

Table 2: Heavy metals levels $(\mathrm{mg} / \mathrm{kg})$ vegetables from Gwallaga, Industrial area, Bauchi State

\begin{tabular}{llllll}
\hline Samples & $\mathrm{Mn}$ & $\mathrm{Zn}$ & $\mathrm{Cd}$ & $\mathrm{Pb}$ & $\mathrm{As}$ \\
\hline Amaranthus & $3.12 \pm 0.023$ & $2.08 \pm 0.012$ & $\mathrm{BDL}$ & $0.05 \pm 0.014$ & BDL \\
Habiscussa bdariffa & $1.52 \pm 0.033$ & $0.60 \pm 0.021$ & $\mathrm{BDL}$ & $0.04 \pm 0.015$ & BDL \\
Allium cepa leaves & $1.50 \pm 0.032$ & $0.95 \pm 0.032$ & $\mathrm{BDL}$ & $0.07 \pm 0.012$ & BDL \\
FAO/WHO & 0.001 & 27.3 & 0.20 & 0.3 & Nil \\
\hline \multicolumn{5}{c}{ BDL } \\
\hline
\end{tabular}

$B D L=$ below detectable limit

Table 3: Soil-vegetable bio-concentration factor coefficients (\%) of heavy metals

\begin{tabular}{lllllll}
\hline Samples & $\mathrm{Mn}$ & $\mathrm{Zn}$ & $\mathrm{Cd}$ & $\mathrm{Pb}$ & $\mathrm{As}$ & Efficacy \\
\hline Amaranthus & 0.329 & 1.136 & 0.00 & 0.111 & 0.00 & 0.315 \\
Habiscussa bdariffa & 0.160 & 0.327 & 0.00 & 0.089 & 0.00 & 0.115 \\
Allium cepa leaves & 0.158 & 0.519 & 0.00 & 0.155 & 0.00 & 0.166 \\
\hline
\end{tabular}

Daily Intake of Metal through Vegetables: Table 4 presents the results of daily intake of metal (DIM) for heavy metals in vegetable samples. Various routes of exposure to humans do exist, yet the most significant is the food chain (David and Minati, 2018). The DIM of $\mathrm{Mn}, \mathrm{Zn}$ and $\mathrm{Pb}$ were 1.149, 0.766 and 0.018; 0.560, 0.022 and $0.015 ; 0.553,0.350$ and 0.026 for children and $0.246,0.164$ and $0.004 ; 0.120,0.047$ and 0.003, $0.118,0.075$ and 0.006 for adult in amaranthus, habiscussa bdariffa and allium cepa leaves respectively. Estimating heavy metal exposure levels is indispensable in determining organism health risk (Singh et al., 2010).

The DIM for Mn was found to be the highest in amaranthus for children and estimated to be 1.149 $\mathrm{mg} /$ person/day, which greater than one; these signifying children were found to be more prone to heavy metal contagion than the adult. The order of DIM for the metals is as follows: $\mathrm{Mn}>\mathrm{Zn}>\mathrm{Pb}$ in the same order for all vegetable samples.
Hazard index: Table 5 presents the results of the hazard index (HI) for heavy metals in vegetable samples. The findings show that $\mathrm{HI}$ values of $\mathrm{Zn}$ for amaranthus and allium cepa leaves for children and $\mathrm{Pb}$ for amaranthus, hibiscus sabdariffa and allium cepa leaves for both children and adults were above 1, except in hibiscus sabdariffa for adults. When HI exceeds one, this means there are potential health effects from exposure (David and Minati, 2018).

The high HI for Zn observed in amaranthus (7.12) and allium cepa leaves (2.46) for children, and $\mathrm{Pb}$ for amaranthus, hibiscus sabdariffa, and allium cepa leaves for both children and adults, except in hibiscus sabdariffa for adults has signifying provable of health risks for the consumption of the vegetables in the study area. High $\mathrm{HQ}$ for $\mathrm{Pb}$ was also reported in Ghana (David and Minati, 2018).

\begin{tabular}{|c|c|c|c|c|}
\hline Metals & Age group & Amaranthus & Habiscussa bdariffa & Allium cepa leaves \\
\hline \multirow[t]{2}{*}{$\overline{M n}$} & Children & 1.149 & 0.560 & 0.553 \\
\hline & Adult & 0.246 & 0.120 & 0.118 \\
\hline \multirow[t]{2}{*}{$\mathrm{Zn}$} & Children & 0.766 & 0.022 & 0.350 \\
\hline & Adult & 0.164 & 0.047 & 0.075 \\
\hline \multirow[t]{2}{*}{$\mathrm{Cd}$} & Children & 0.000 & 0.000 & 0.000 \\
\hline & Adult & 0.000 & 0.000 & 0.000 \\
\hline \multirow[t]{2}{*}{$\mathrm{Pb}$} & Children & 0.018 & 0.015 & 0.026 \\
\hline & Adult & 0.004 & 0.003 & 0.006 \\
\hline
\end{tabular}




\begin{tabular}{cllll}
\multicolumn{6}{c}{ Table 5: Health Risk Index (HRI) inAmaranthus, Habiscussa bdariffa, and Allium cepa leaves } \\
\hline Metals & Age group & Amaranthus & Habiscussa bdariffa & Allium cepa leaves \\
\hline $\mathrm{Mn}$ & Children & 0.104 & 0.051 & 0.050 \\
& Adult & 0.022 & 0.011 & 0.011 \\
$\mathrm{Zn}$ & Children & 2.553 & 0.073 & 1.167 \\
& Adult & 0.547 & 0.157 & 0.250 \\
$\mathrm{Cd}$ & Children & 0.000 & 0.000 & 0.000 \\
& Adult & 0.000 & 0.000 & 0.000 \\
$\mathrm{~Pb}$ & Children & 5.143 & 4.285 & 7.429 \\
& Adult & 1.143 & 0.857 & 1.714 \\
\hline
\end{tabular}

Conclusion: This study determined the level of heavy metals ( $\mathrm{Mn}, \mathrm{Zn}, \mathrm{Cd}, \mathrm{Pb}$, and $\mathrm{As}$ ), the results revealed that the level of the investigated metals in soil and water were below FAO/WHO and WHO of soil and water standards respectively. The bio-concentration factor value revealed that amaranthus had the highest factor for $\mathrm{Mn}$ and $\mathrm{Zn}$, while allium cepa leaves had a higher factor for $\mathrm{Pb}$ and, habiscussa bdariffa had the lowest factor for $\mathrm{Mn}, \mathrm{Zn}$, and $\mathrm{Pb}$. Furthermore, the findings on the DIM, and HI revealed that consumption of amaranthus and allium cepa leaves of $\mathrm{Zn}$ for children and $\mathrm{Pb}$ for amaranthus, hibiscus sabdariffa and allium cepa leaves for both children and adults could pose human health risks due to high level of $\mathrm{Zn}$ and $\mathrm{Pb}$.

\section{REFERENCE}

Adedokun, AH; Njoku, KL; Akinola, MO; Adesuyi, AA; Jolaoso,Anuoluwapo O (2016). Potential Human Health Risk Assessment of Heavy Metals Intake via Consumption of some Leafy Vegetables obtained from Four Market in Lagos Metropolis, Nigeria. J. Appl. Sci. Environ. Manage. 20(3): 530539.

Alinno, IJ (2008). Determination of Heavy Metals in Leaves of Pumpkin (Telferia Occdentalis) and Spinach (AmaranthusCruetus) Along Major Highways in Owerri, South Eastern Nigeria. J.Chem.Soc. Nig. 33(1): 150-151.

Arora, M; Kiran, B; Rani, S; Rani, A; Barinder, K; Mittal, N (2008). Heavy Metal Accumulation in Vegetables Irrigated with Water from Different Sources. Food Chem. 111: 811-815.

Barambu, AU; Maigari, AU; Sulaiman, MB (2020). Levels of Heavy Metals in a Groundwater around a Municipal Solid Waste Dumpsite in Bauchi, Nigeria: Assessing the Health Impact. J. Chem. Soc. Nig. 45(2): 316-323.

Chibuike, GU; Obiora, SC (2014). Heavy Metal Polluted Soils: Effect on Plants and Bioremediation Methods. App Environ Soil Sci.doi.org/10.1155/2014/752708
David, SK; Minati, S (2018). .Levels and Health Risk Assessment of Heavy Metals in Soil, Water, and Vegetables of DaresSalaam, Tanzania. $J$. Chem.doi.org/10.1155/2018/1402674

Duke CVA; Williams, CD (2008). Soil Pollution. In: Chemistry for Environment and Earth Sciences. CRC Press: Taylor and Francis Group.

FAO/WHO (2007). Expert Committee on food additives. Cambridge University Press, Cambridge, pp 329-336.

FAO/WHO (2011). Joint Report, Food Standard Programs Codex Committee on Contaminants in Foods. (CF/5 INF/1), Rome.

Ftsum, G; Abraha, G (2018). Health risk assessment of heavy metals via consumption of spinach vegetable grown in elallariver. Bull. Chem. Soc. Ethiop. 32(1): 65-75.

Garba, ST; Tukur, A; Akan, JC (2018). Phytoextraction Potential of the Plant, TriticumAestivum for the Metals; Zinc, Cobalt, Copper, Lead and Nickel. Amr. J. Eng. Res. 7(11): 263-276.

Gebeyehu, HR; Bayssia, LD (2020). Levels of heavy metals in soil and vegetables and associated health risks in Mojo area, Ethiopia. PLoS One 15(1): 122.

Gemeda, FT; Guta, DD; Wakjira, FS; Gebresenbet, G (2020). Occurrence of heavy metal in water, soil, and plants in fields irrigated with industrial wastewater in Sabata town, Ethiopia. Environ. Sci. Poll. Res. doi.org/10.1007/s11356-020-10621-6

Grzetic, I; Ghariani, RAH (2008). Potential health risk assessment for soil heavy metal contamination in the central zone of Belgrade (Serbia). J. Serb. Chem. Soc.73(89): 923-934. 
Gupta, S; Jena, V; Jena, S (2013) Assessment of heavy metal contents of green leafy vegetables. Croa. J. Food Sci. Techno. 5(2): 53-60.

Hazrat, A; Ezzat, K; Ikram, I (2019). Environmental Chemistry and Ecotoxicology of Hazardous Heavy Metals: Environmental Persistence, Toxicity, and Bioaccumulation. $J$.

Chem. doi.org/10.1155/2019/6730305

Kabata-Pendias, A; Pendias, H (2001). Trace Elements in Soils and Plants. 3rd Edition, CRC Press, Boca Raton, p. 403.

Kudirat, LM; Funmilayo, DV (2011). Heavy Metal Levels in Vegetables from Selected Markets in Lagos, Nigeria. Afr. J. Food Sci.Techno. 2(1): 1821.

Mahmood, A; Malik, RN (2014). Human health risk assessment of heavy metals via consumption of contaminated vegetables collected from different irrigation sources in Lahore, Pakistan. Arab. J. Chem. 7: 91-99.

Naser, HM; Sultana, S; Gomes, R; Noor, S (2012). Heavy metal pollution of soil and vegetable grown near roadside at Gazipur, Bangladesh. J. Agric. Res. 37: 9-17.

Ogbonna, PC; Okezie, N (2011). Heavy metal level and macro nutrient contents of road side soil and vegetation inUmuahia, Nigeria. Terr. Aqua. Environ. Toxico. 5: 35-39.

Qingwei, B; Qingshan, L; Handan Z; Hongmei C; Wenwen G; Xin ; Ke, L; Yibo, C (2020). Concentrations, Spatial Distributions, and Sources of Heavy Metals in Surface Soils of the Coal Mining City Wuhai, China. $J$. Chem.doi.org/10.1155/2020/4705954

Raymond, AW; Felix, EO (2011). Heavy Metals in Contaminated Soils: A Review of Sources, Chemistry, Risks and Best Available Strategies for Remediation. Int. Scho. Res. Not. doi.org/10.5402/2011/402647

Reynolds, TW; Waddington, SR; Anderson, CL (2015). Environmental impacts and constraints associated with the production of major food crops in Sub-Saharan Africa and South Asia. Food Sec. 7: 795-822.

Sharma, S; Nagpal, AK; Kaur, I (2018) Heavy metal contamination in soil, food crops and associated health risks for residents of Ropar wetland, Punjab, India and its environs. Food Chem. 255: 15-22.

Singh, A; Sharma, RK; Agrawal, M; Marshall, FM (2010) Risk assessment of heavy metal toxicity through contaminated vegetables from waste water irrigated area of Varanasi, India. Trop. Ecolo. 51(2): 375-387.

Sulaiman, MB; Asegbeloyin, JN; Ihedioha, JN; Oyeka, EE; Oji, EO (2019a). Trace Metals Content of Soil around a Municipal Solid Waste Dumpsite in Gombe, Nigeria: Assessing the Ecological and Human Health Impact. J. Chem. Risk. 9(3): 173190.

Sulaiman, MB; Maigari, IA; Yahaya, Y (2019b). Health Risk Assessment of Heavy Metals Accumulation in Tomatoes Irrigation Farms at Kwadon, Gombe, Nigeria. ATBU. J. Sci. Techno. Edu. 7(2): 271-280.

Sulaiman, MB; Salawu, K; Zubaru, I (2016). Assessment of Potential Health Risks Associated with Remediated and Non-Remediated Soils at Illegal Mining Compound in Dareta, Zamfara, Nigeria. Int. J. Inno. Sci. Engr. Technol. 3(10): 151-160.

Sulaiman, MB; Yahaya, Y; Gimba, AM (2020). Groundwater Quality Assessment using Water Quality Index in Gombe Town, Gombe, Nigeria. Nig. Res. J. Chem. Sci. 8 (1): 104-114.

Tasrina, RC; Rowshon, A; Mustafizur, AMR; Rafiqul, I; Ali, MP (2015) Heavy metals contamination in vegetables and its growing soil, J Environ Anal.. Chem. 2(3): 142.

US-EPA IRIS (2003). Integrated Risk Information System data base, US Envrion. Protec. Agency.

US-EPA IRIS (2006). United States, Environmental Protection Agency, Integrated RiskInformation System. <http://www.epa.gov/iris/substS>.

Varalakshmi, LR; Ganeshamurthy, AN (2010). Heavy Metals Contamination of Water Bodies, Soils and Vegetables in Peri Urban Areas of Bangalore City of India.19th. World Congress of Soil Science, Soil Solutions for a Changing World. 1-6 August 2010. Brisbane, Australia.

Vhahangwele, M; Khathutshelo, LM (2018). Environmental Contamination by Heavy Metals, Heavy Metals, Hosam El-Din M. Saleh and Refaat 
F. Aglan, Intech Open, DOI: Zhuang, P; McBride, MB; Xia, H; Li, N; Li, Z (2009). 10.5772/intechopen.76082.

Health risk from heavy metals via consumption of food crops in the vicinity of Dabaoshan mine,

WHO (1996). Background document for development of WHO guidelines for drinking-water quality.

WHO (1998). TheWorld Health Report Life in the 21st century. A vision for all Report of the Director-General World Health Organization, South China. Sci. Total Environ. 407: 1551-1561.

Zwolak, A; Sarzyńska, M; Szpyrka, E (2019). Sources of Soil Pollution by Heavy Metals and Their Accumulation in Vegetables: a Review. Wat. Air Soil Poll.doi.org/10.1007/s11270-019-4221-y 